Vol. 21, $n^{\circ} 1 \mid 2017$

Varia

\title{
Death Row Resistance, Politics and Capital Punishment in 1970s Jamaica
}

James Campbell

\section{CpenEdition}

\section{Journals}

\section{Electronic version}

URL: http://journals.openedition.org/chs/1715

DOI: $10.4000 /$ chs. 1715

ISSN: 1663-4837

\section{Publisher}

Librairie Droz

\section{Printed version}

Date of publication: 1 January 2017

ISSN: 1422-0857

\section{Electronic reference}

James Campbell, « Death Row Resistance, Politics and Capital Punishment in 1970s Jamaica », Crime, Histoire \& Sociétés / Crime, History \& Societies [Online], Vol. 21, n | 2017, Online since 01

January 2019, connection on 06 September 2019. URL : http://journals.openedition.org/chs/1715 ; DOI : 10.4000/chs. 1715

\section{This text was automatically generated on 6 September 2019}

(C) Droz 


\section{Death Row Resistance, Politics and Capital Punishment in 1970s Jamaica}

James Campbell

1 In February 1972, Mario Hector and Winston Williams were found guilty in Kingston, Jamaica, of the murder of Nicholas Miller. A security guard employed at the First National City Bank, Miller was shot dead on 6 November 1970 in the course of a robbery. Hector and Williams denied any involvement in the crime. An apprentice printer before his arrest, Hector claimed in an unsworn statement at his trial that on the day of the murder he had gone "to the Jones Town post office where he posted some finished lessons for correction," before heading to a department store to purchase stationery and then on to a library to carry out some research. He also alleged that he was beaten repeatedly by police before signing a "confession" that was written without his input and which he was not permitted to read. Williams denied ever having met Hector before he was taken into custody and could not recall his whereabouts at the time Miller was killed. ${ }^{1}$

On their conviction, Hector and Williams were both sentenced to death, which was then the mandatory penalty for murder in Jamaica, and immediately transferred to death row at the St Catherine District Prison in Spanish Town. On arrival, they were met by the prison's senior warder, assigned a religious affiliation when they declared they had none, and escorted to a reception room where they were fingerprinted, photographed and searched. They were dressed in prison uniforms with "the word 'Condemned' written in bold black letters across the back" and taken to A block, which at that time housed the death cells. There they were beaten by guards and locked in solitary confinement. ${ }^{2}$ In keeping with English common law precedent, executions had traditionally been conducted swiftly in Jamaica, usually within a few weeks of sentencing, but that was no longer the norm by the 1970s due principally to an increasingly lengthy appeals process. Hector spent three years on death row and Williams seven years before their sentences were commuted to life imprisonment by Jamaica's Governor-General, Florizel Glasspole. 
3 The history of the death penalty in Jamaica, and the wider Anglophone Caribbean since the 1970s has mostly been told by legal scholars who have focused on a series of appeals heard by the Judicial Committee of the Privy Council in the United Kingdom, which has remained Jamaica's highest appellate court since independence in 1962. In those studies, the main explanatory factors for developments in Caribbean capital punishment are identified as European legal and penal cultures, the activities of international human rights organisations and London-based lawyers, and the political concerns of the UK government. ${ }^{3}$ By contrast, there has been little analysis of the events in local courts and prisons where death penalty appeals originated and condemned prisoners awaited their fate. The years that Mario Hector and Winston Williams spent under sentence of death coincided with critical events in the modern history of capital punishment in Jamaica that played a key role in initiating a concerted national and international campaign against executions that involved lawyers, activists, government ministers and members of the public. This article documents these events and argues that they stemmed in important ways from the actions of condemned prisoners themselves. It uncovers wideranging acts of resistance committed by death row prisoners that forced capital punishment onto the political agenda in Jamaica, generated significant doubts about the justice and efficacy of the death penalty, and led to an unofficial moratorium on executions in the late-1970s during which numerous death sentences were commuted. In this way, prisoner resistance supplemented, and sometimes even underpinned, concurrent legal challenges to capital punishment. It generated a spirit of resilience among the condemned that helped them to endure the horrendous conditions of their incarceration and, in the short-term at least, proved more successful than court action in securing relief for individual convicts from the gallows.

4 The article draws on a wide-range of previously neglected sources. At the heart of the analysis is Mario Hector's own, remarkable account of his life under sentence of death. This work offers unparalleled insights into the ways that condemned convicts experienced and challenged their imprisonment and death sentences in 1970s Jamaica, but it is not an unproblematic source. It was written in the early-1980s, several years after the events that it narrates. Hector had established himself as a prominent prison activist and organiser by this point, suffered years of deprivation and abuse, raising concerns about the reliability of his recollections. That he had also become involved with the work of the Jamaica Council for Human Rights and undertaken a sociology degree also raises the possibility that his views of the mid-1970s were coloured - whether deliberately or inadvertently - by his later experiences and evolving political beliefs. Hector also wrote under difficult conditions. Although no longer facing execution, he remained incarcerated and faced the constant threat that guards might discover his manuscript. He relied on fellow inmates to hide papers and smuggle them to the outside where the Jamaica Council for Human Rights coordinated the book's publication. The vehemence with which Hector condemns Jamaica's legal system, prisons and wider political culture suggests that the risks he took did little to inhibit his writing, though it should be noted that it was in the interests of both Hector and the JCHR - which had long fought against capital punishment and worked on Hector's case - to stress the humanity of condemned prisoners and the injustices perpetrated by the Jamaican courts.

5 In a foreword to the book the JCHR described some of Hector's hypotheses as "difficult to support", citing as an example his claim that colonialism was responsible for capital punishment. This gives further reason to believe that the views Hector expressed were 
largely his own. Moreover, his descriptions of prison conditions and acts of resistance are corroborated by other sources, including interviews with other condemned inmates, extensive newspaper reports, legal records, and two major inquiries into capital punishment commissioned by the Jamaican government. The first of these inquiries, which reported in June 1975, was chaired by the lawyer and human rights activist $\mathrm{Dr}$ Lloyd Barnett who was charged with investigating the kidnapping of a prison warder by death row inmates, including Hector, on the night of 26 December 1974. The second inquiry, headed by H. Aubrey Fraser, the Director of the Norman Manley Law School, had a broader remit to assess whether the death penalty in Jamaica should be "abolished, limited or modified", and in what conditions condemned prisoners should be held. After eighteen months of investigations that involved psychologists and social workers interviewing dozens of condemned inmates and submissions from a range of legal, political, religious and human rights bodies, as well as member of the public, the Fraser Report was published in $1981 .{ }^{4}$

6 In identifying death row prisoners as key actors in the history of capital punishment, this article pioneers a new direction for historical scholarship on the subject. There is a small but powerful sociological and criminological literature on the "living death" endured by prisoners who have been condemned to die. Largely focused on the United States, this work finds little evidence of death row resistance and, indeed, identifies conditions on death row that strongly militated against collective action..$^{5}$ As sociologist David Garland has argued, the death penalty in the U.S. became increasingly regulated, medicalised and sanitised during the twentieth century, and death row developed into the most tightly managed of all carceral environments. Criminologist Robert Johnson described Alabama's death row in the late-1970s as "like a tomb." Consisting of four tiers of cells in two blocks, death row prisoners were separated from the outside world by five locked gates, and such was the construction and layout of the cells and the regulation of prisoners' daily routines that communication even between tiers of cells within the same block was "almost impossible". ${ }^{6}$ While prisoners might talk and play games with men in neighbouring cells, and, through these activities, provide each other with some psychological support, there was almost no scope for organised resistance. On the contrary, Johnson concluded that the condition of death row inmates was characterised by powerlessness, fear and an emotional emptiness that bred apathy, passivity and decay.

7 Historians of the twentieth century death penalty have rarely focused their attention on death row, concentrating instead on movements to abolish capital punishment, legal challenges to death sentences and changes over time in methods of execution. ${ }^{8}$ Ethan Blue's work on death row culture in 1930s California and Texas is an exception. Blue notes that historians have paid considerable attention to the transformation of the practice of capital punishment in the United States, tracing the emergence of private, bureaucratized and sanitized killings carried out in electric chairs, gas chambers, and by lethal injection, but they have generally ignored the ways that condemned prisoners, "responded" to what he calls "the emergent killing regimes" of the mid-twentieth century. ${ }^{9}$ While acknowledging that the condemned prisoners in his study rarely engaged in explicit acts of resistance, Blue argued that they were routinely unwilling to "die on the state's terms." Instead, they strived to shape the manner in which they passed their final days and the way in which they died through forging communal bonds based on songs, religion 
and gallows humour, and sometimes taking their own lives before the executioner could do his work. ${ }^{10}$

There is evidence that similar acts of self-determination occurred on death row in Jamaica in the 1970s. Condemned prisoners formed close personal attachments with each other, sang hymns together and, in at least one case, cheated the hangman by committing suicide soon after an execution date was set. ${ }^{11}$ As Blue argues, these individual and communal assertions of humanity and dignity mattered on their own terms for the condemned, their families and the many state officials involved in the processes of execution. They were an implicit rebuke and challenge to the "meanings of death" that the state sought to impose. Yet the accounts of Hector and others demonstrate that in the Jamaican context they also served as an essential basis for more overtly political oppositional acts that fundamentally destabilised capital punishment. In this way, the case of Jamaica's death row in the 1970s offers evidence of what criminologist Ashley Rubin calls the processual nature of prisoner resistance. Rubin argues that in their efforts to challenge Foucauldian accounts of prisons as "totalising institutions," scholars "have overused (and misused) the label 'resistance" to describe prisoner behaviours that "challenge the prison regime's personnel, rules, values, or power," but lack political intent. He proposes the term "friction," as a more accurate definition of behaviours that principally benefit individual prisoners and are not "consciously aimed at undermining the authority of the prison regime." Rubin stresses that there is no binary opposition between friction and resistance. Rather, they exist on a continuum. Friction can be a precursor to or preparation for resistance, and particular prisoner behaviours can operate as either friction or resistance depending on their circumstances and motivations ${ }^{12}$ To understand why and how resistance developed on Jamaica's death row requires looking both within and beyond the prison walls, placing prisoners at the centre of the narrative and taking their capacity for political thought and action seriously, but also - as recent studies of the black prison rights movement in the United States have shown - investigating the social and political contexts in which prisons and prisoners are situated and the ramifications of prisoners' acts on the outside. ${ }^{13}$

The remainder of this article addresses the causes, course and consequences of death row resistance in 1970s Jamaica in four parts. It focuses first on the conditions in which inmates sentenced to death in Jamaica were incarcerated; second, on acts of resistance by condemned prisoners; third, on unsuccessful legal challenges to Jamaica's juvenile death penalty laws that were central to the decision to grant clemency to Mario Hector in 1975, and fourth, on public criticism and political debates about the future of capital punishment in Jamaica that provided the context in which Winston Williams's life was spared and Pratt and Morgan first entered death row in 1979.

\section{Death Row, Jamaica}

10 The St Catherine District Prison has housed all condemned male prisoners and been the site of all executions in Jamaica since 1900. When Mario Hector and Winston Williams were convicted in February 1972, condemned prisoners were held in A block, but four months later death row was moved to an expanded and more secure location on the upper floor of the prison's Gibraltar Block where twenty-six single-person cells were arranged on either side of a corridor. ${ }^{14} \mathrm{~A}$ further three cells were situated adjacent to the death chamber that housed the gallows and used to hold inmates in the days immediately 
preceding their scheduled execution. The row was not as tightly managed as was typical in the United States, but it was, and remained, a brutal, austere, fetid and unsanitary place, filled with desperate men and prone to regular outbreaks of violence that were sometimes perpetrated by prisoners, but more often by poorly paid, overstretched and mostly untrained guards. ${ }^{15}$ Each cell was furnished with a narrow bed, a table and chair, all made of concrete, and prisoners were provided with a water mug and a slop bucket. ${ }^{16}$ They also had access to a shower, were granted two visits and could write two letters each week and were allowed into the corridor between their cells for fifteen minute periods of exercise two or three times per week. An enclosed outdoor recreation area reserved for condemned men was unused due to staff shortages. ${ }^{17}$ The cell doors remained closed at all other times except for a few minutes each morning when prisoners were taken, usually in groups of three, to empty their buckets, fill their water jugs and wash. ${ }^{18}$ Radios and reading material of any kind were prohibited in the cells, as were all items of personal hygiene. Prisoners were not permitted to wear shoes and were rarely provided with changes of clothes, and then only at the whim of prison guards. As much as the physical severity of these conditions, Hector recalled the tedium of life on the row. Echoing the sentiments of condemned prisoners in the United States, he wrote of, "time...seemingly endless time...Sitting empty-eyed...Standing because you're tired of sitting... Consideration...frustration...silence...Time...silence...the death sentence...time." ${ }^{19}$

11 Record numbers of Jamaican prisoners experienced the stultifying conditions of death row in the 1970s, due in large part to the island's spiralling murder rate. ${ }^{20}$ In 1962, there were 57 reported murders in Jamaica, but by 1972 that figure had more than trebled to 188 and by 1980 it stood at $699 .{ }^{21}$ This was a unique moment in the history of Jamaican murder. Prior to independence, most homicides involved domestic violence and from the mid-1980s an even greater increase in the murder rate was linked to transnational drugs trafficking. The high murder rate of the late-1960s and especially the 1970s, however, was mainly due to a post-independence intensification of links between politicians and criminal gangs, as Jamaica's two main parties-the Jamaican Labour Party (JLP) and the People's National Party-forged mutually beneficial connections with violent street gangs. In return for promises of homes, jobs and protection from the police, criminal dons organised whole communities to support their chosen candidates. The violence which tended to spike around elections - was most intense in west Kingston which was home to large numbers of socially excluded migrants from rural communities and where poverty and unemployment were so entrenched "that people were prepared to fight or kill to get their candidate elected and thus tap into the political-patronage network". ${ }^{22}$ Many of the prisoners on death row were drawn from such communities. The Fraser Report found in 1981 that, "[t]he areas in which these men grew up are usually neighbourhoods of concern to the police because of the frequent violence, gang warfare and political conflicts which are prevalent." Condemned prisoners understood that these conditions had contributed to their own violent pasts: "They argue quite vociferously that the culture of the neighbourhood imposes on them the need to be tough and ready to defend the 'territory', (their own neighbourhood) from attack and interference from 'outsiders". ${ }^{23}$

12 As Jamaica's homicide rate increased from approximately 4 per 100,000 in the early-1960s to 17 per 100,000 in the late-1970s, it placed a huge strain on the country's police, criminal justice apparatus and prison system. The ruling PNP government responded to the violence by enacting two new and controversial pieces of legislation. First, the 
Suppression of Crime Act (1974), gave the police broad new powers to carry out searches without a warrant and make arrests on the basis of reasonable suspicion. Second, the Gun Court Act (1974), created a new court designed to speed up the trial of crimes involving illegal firearms by significantly restricting defendants' due process rights, but this did not extend to capital cases, and the proportion of murders that were solved fell sharply from more than 90 percent in the early-1960s to just 50 percent by the late-1970s. Many violent criminals in this period were able to exploit their community and political connections to avoid prosecution or even flee Jamaica, ${ }^{24}$ but still there was a significant increase in total murder convictions. Death by hanging was the mandatory penalty for murder and the number of death sentences handed down by Jamaican courts each year grew from roughly fourteen in the late 1960s to an average of nearly fifty in the 1970 s. $^{25}$ What is more, the men who were condemned to death - and in this period they were, with three known exceptions, all men ${ }^{26}$ - were more likely than in previous eras to appeal their convictions not only in Jamaican courts but also to the Judicial Committee of the Privy Council and this meant that prisoners spent far longer on death row than ever before before their cases were resolved. ${ }^{27}$ Among prisoners condemned to hang in this period who were eventually put to death, no man spent longer on the row than Thomas Ransford, who was held for more than nine years and three months between his conviction on 30 April 1974 and his execution on 19 July 1983. At least seven other men were incarcerated for more than seven years before their executions and several men whose sentences were eventually commuted were held for even longer. ${ }^{28}$

By 1975, there were thirty-six men awaiting execution in Jamaica and by January 1979, after three years during which no executions were carried out, the figure had risen to seventy-nine. ${ }^{29} \mathrm{~A}$ report, based on interviews with forty condemned prisoners conducted in August and September 1979, provides an insight into the lives of these men prior to their convictions. Among the findings were that most of the men were from low socioeconomic backgrounds, grew up in violent neighbourhoods and came from large but unstable families in which the children "tend[ed] to be fathered by several different men" and frequently had to look after themselves. Many of the prisoners blamed their current circumstances on parental neglect, and particularly noted beatings and ill-treatment they had suffered at the hands of men with whom their mothers cohabited, but who were not their biological fathers. The average age of the prisoners when they were interviewed was twenty-six, though their average age was just twenty-three at the time of the crimes for which they were sentenced to hang. ${ }^{30}$ Only five of the men were married (including three who murdered their wives), but many more were in stable relationships and some were visited by girlfriends on death row. Most of the men recalled that their first sexual experience occurred before the age of ten, and twenty-six had children, of whom eighteen had more than one child. Thirteen of the men were practicing Rastafarians and many others wore dreadlocks. Only fourteen were literate, a consequence of infrequent attendance at school, which in turn was normally due to having to help out with work at home, including tending to animals and caring for younger siblings, and also a lack of money for bus fares and lunch. In terms of occupational status, thirty-one men were described in the report as "unskilled" and most had jobs that were "sporadic" and "seasonal" and provided a low and irregular income. ${ }^{31}$ Mario Hector's pre-conviction employment as an apprentice printer and his literacy marked him out from the majority of condemned prisoners. 
14 Amidst the indignities and violence of life on the row, there were moments of humanity among the prisoners. On Hector's first night in A Block, the man in the neighbouring cell rapped on the wall, "expressed his condolences" and warned that the warder on duty would "brutalize us" if he heard any noise coming from the cells. The following morning, the same man initiated Hector more generally in "the rules and regulations that governed the Row and the inherent norms of day-to-day survival". ${ }^{32} \mathrm{~A}$ decade later, the condemned prisoner Anthony "Fines" Ashwood, who spent ten years on death row following a murder conviction in 1983, also drew strength from fellow inmates. "Men banded together," he explained, "because we all faced the same fate". ${ }^{33}$ As Johnson found among the death row population in Alabama, however, prisoners nonetheless deteriorated both physically and psychologically while on death row. A psychological examination carried out in April 1991 on Ivan Morgan, who had been under sentence of death since 1979 and had, on three occasions, been moved to the death cell adjacent to the gallows only for his execution to be postponed at the last minute, provides an unusually detailed and official record of the impact of death row on an inmate's mental health. In the course of the examination, Morgan was hyperactive, "laughed a lot" and gave responses "that were clearly inappropriate and euphoric". The report found that Morgan was extremely emotionally disturbed and on the verge of psychosis. He suffered from acute insomnia, regularly envisioned the death cell and spoke of the traumatic cycles of hope and despair that he experienced as, one after another, his dates with death came and went: "We get hope - then it is dashed away - then hope - it is terrible". He had "only occasionally coherent periods of cognition" and his "emotional organization [was] breaking down". ${ }^{34}$

The spectre, sounds, and smells of death were everywhere in Gibraltar Block. Prisoners interviewed in 1975 by the Barnett Commission complained bitterly that guards taunted them about their impending hangings and terrifying rumours circulated about the experience of dying on the gallows. The situation was only intensified in the days surrounding executions. Until steps were taken to muffle the noise in the wake of prisoner complaints, the lever which activated the gallows "made a disturbing sound that reverberated throughout the institution". Prisoners also had "haunting" memories of a cart that was wheeled past their cells carrying a crude, prison-made coffin in preparation for a hanging and would later pass back again taking the body of the executed prisoner for burial. Anthony Ashwood, who estimated that between thirty and thirty-five men were executed during his time on death row in the 1980s, recalled that the cart "have on two wheels and a pure squeaking it make when dem a push it." He remembered too the graveyard, situated behind the prison kitchen and near to a football pitch, ${ }^{35}$ where executed prisoners were laid to rest within sight of those who still awaited their date with the gallows. Reaching up to peep through a vent high in his cell wall, Ashwood "could see the grave dem a dig[.]" ${ }^{36}$

\section{Resistance on Death Row}

16 Mario Hector's account of his time on death row shows that harsh physical and psychological conditions, coupled with the growing delays between sentencing and execution, were critical to the growth of convict resistance. Hector himself claimed that he appealed his case to the Judicial Committee of the Privy Council in London not because he "hoped to find justice" in what he called "that ancient capital of colonialism", but rather "to earn some time" in which to develop a plan to reverse his conviction or in 
some other way to save his life. ${ }^{37}$ In conjunction with other prisoners on the row, Hector persistently challenged the conditions of his incarceration and his death sentence while his appeal wound its way through the courts. Most dramatically, on 26 December 1974, he was among a group of up to twenty-four death row prisoners who seized one of the prison warders - a man named Clarke - and held him hostage. The Barnett commission was established in response to this incident and found that a litany of security lapses had facilitated the kidnapping. At least two months earlier, the prisoners had obtained hacksaw blades with which they painstakingly cut through the bars of their cells. They used oil from their food to lubricate the blades and stuffed the cuts with soap to keep the bars in place and cover up their work. There were normally two warders assigned to Gibraltar Block, but on the night in question one was called away to do yard patrols due to staff shortages elsewhere in the prison and this left Warder Clarke alone. At about midnight, Clarke attended one of the prisoners who had called for some water and he was seized as soon as he stepped into the death row corridor. In the ensuing commotion, seven prisoners attempted to flee, but five returned to the cell block and barricaded themselves after they encountered Senior Warder Murray who had heard Clarke cry for help. The two other men were found later the same night in the prison wash-house where they were brutally beaten by guards. ${ }^{38}$

17 The Acting Director of Prisons alleged that the men who kidnapped Warder Clarke were planning a massive jail break and their subsequent criticism of prison conditions was nothing more than a cover story adopted after the escape attempt failed, but the Barnett Commission concluded that there was no credible evidence to support this interpretation and the prisoners' aim all along had been to bring various grievances to public attention. To this end, the prisoners refused to release Clarke until they were permitted to meet with the Prime Minister, Michael Manley, the chairmen of the Jamaica Council of Churches and the Jamaica Council for Human Rights and two journalists. A deal was eventually brokered whereby Clarke was freed and five of the prisoners, including Hector, were granted an audience with Manley at which they outlined their complaints. ${ }^{39}$ These focused on four main issues: the inadequacy of legal representation in capital trials and appeals, delays in the legal process, specific individual cases of injustice and hardship, and the manner in which executions were carried out. ${ }^{40}$

18 In Hector's account, the kidnapping was not the result of lax security but rather one element of a broader, coordinated campaign of resistance that had originated in attempts to improve conditions on death row that dated back many months. Among the prisoners' complaints about their treatment on death row were a "lack of proper medical attention, lack of sunlight, inadequate exercise, insanitary conditions, infrequency of baths and the attitudes of Prison staff frustrating their visitors". Interviewed after the event, Hector who served as chief spokesman for the prisoners - explained that it had been necessary to take such action, because the prisoners' earlier efforts, to "expose the injustices manifested by Judicial administration and [the] inhuman practices in the prison", had proved unsuccessful. ${ }^{41}$

19 Hector traced the origins of the resistance campaign against death row conditions to 1972 when prison guards attacked Eaton Baker, one of six young men who had been condemned to die for the November 1969 killing of Warder Reginald Taitt during a riot at Hill Top prison in St Ann's parish. Other prisoners on death row started shouting in protest and, as Baker fought back, their cries were taken up by inmates in other cell blocks until the entire prison was in "a state of pandemonium". ${ }^{42}$ Anticipating violent 
repercussions from the guards, the condemned prisoners planned a collective response. Knowing they could not win a physical confrontation, they agreed that they would refuse to leave their cells when called out the following morning. After one prisoner was finally coaxed out and beaten, a second tipped over his slop bucket so the warders would have to cross the mess to get at him, and declared that he would die "right there in the filth" rather than leave his cell. The men then demanded a meeting with the prison superintendent to outline their grievances, and when that was refused they went on hunger strike. They were again soon joined in their action by prisoners in neighbouring cell blocks. ${ }^{43}$ Eventually, the superintendent did agree to a meeting and it was at this point that Hector was chosen to represent the death row inmates. He elicited a promise from the superintendent that the assault on Baker would be investigated and, while there is no evidence that this ever happened, the superintendent did make several other concessions, including allowing death row prisoners access to books and newspapers and the right to keep soap, toothpaste and towels in their cells. ${ }^{44}$

This small victory appears to have done little in the short term to improve death row conditions and certainly did not address the prisoners' vociferous complaints about the judicial system and the poor legal representation they had at trial and throughout the appeals process. ${ }^{45}$ It did, however, have far-reaching psychological, ideological and practical implications. In Hector's account, the men were no longer filled with "fear and despair", but instead recognised the power of collective action and saw for the first time the significant difference "between death on the gallows and death at the end of a gun or the swing of a baton, while bearing the spirit of resistance" ${ }^{46}$ Allowed access to books, Hector became a vociferous reader and immersed himself in canonical texts of AfricanAmerican resistance and anti-imperialist struggle by Booker T. Washington and Frederick Douglass, and the Black Power prison activists George Jackson and Eldridge Cleaver. He also read the Caribbean writers Marcus Garvey, Walter Rodney and Trevor Munroe, as well as Marx and Fanon. ${ }^{47}$ Inspired by these works, Hector interpreted the circumstances of death row prisoners as an extension of the wider oppression of black and poor people in Jamaica. "To my mind", he wrote, "our condition and status in society had not changed at the point of arrest. It was only a case that the place of our suffering had changed from the ghettos to the prison" ${ }^{48}$ In part, this interpretation reflected a generational shift. Hector recounted that the "older people", alongside whom he was first incarcerated on death row in 1972, "perpetuated the myth that a prisoner of the Row could do nothing to influence the ultimate decision of one's case and survival. They encouraged the idea that all one ought to do was pray, sing, fast and have faith". By contrast, the younger prisoners were more militant. As Hector explained, their concern was "how to save our lives by any means necessary" and they believed that they "would have to personally contribute to any relief that might be forthcoming". ${ }^{49}$ This militancy was a response in part to the oppressive conditions on death row, but Hector suggested it was also borne out of Jamaican independence, or, more precisely, what he called the betrayal of independence. "All of us were born into a society that was telling us we were free and independent people", Hector wrote, "but it was a lie: the lie of emancipation". ${ }^{50}$

21 Although Hector's autobiography was not published until 1984, its analysis of capital punishment is consistent with the views that Hector and other prisoners expressed to the Barnett Inquiry nearly ten years earlier. This suggests that Hector's critical views on the injustice of Jamaican law and the inhumanity of death row were formed during his time under sentence of death, even if his political philosophy likely continued to evolve over 
later years as he became a leading figure in prison protest movements, engaged with the Jamaica Council for Human Rights and successfully completed $O$ levels and the first stages of a B.Sc. Sociology degree. Hector was chosen by his fellow inmates on death row to represent their views in meetings with the Barnett Commission and Prime Minister Manley and this suggest that there was at least some wider sympathy among condemned inmates for his political views. ${ }^{51}$ There is no direct evidence on this point, but death row prisoners were certainly politically engaged. ${ }^{52}$ At a time when so many murders were connected to electoral politics, it is unsurprising that some expressed party political affiliations. Before Rupert Anderson was executed in 1971, he asked Rev. Fr. Francis Kempel S.J. of St. Joseph's Church, Spanish Town to read psalms 18 and 91, and handed him a note, which read: "I am asking the people of Jamaica to vote for Michael Manley in the General Election because I am dying a comrade". ${ }^{53}$ Other expressions of political consciousness were more aligned with Hector's more radical anti-colonialism, such as when condemned prisoners who were Rastafarians interpreted their conviction and sentence as an attack on their distinctive cultural and religious identity. A committee established in 1979 to consider the reform or abolition of the death penalty in Jamaica, found that "Many of the men who wore dreadlocks positively believe that their appearance caused the judge and jury to be biased against them. They argue that Rastas are given a hard time by the agents of the State".${ }^{54}$ In a related vein, the condemned prisoner Anthony Ashwood came to view the death penalty in the 1980s as an instrument of class oppression, arguing that most of the men who were hanged were those who could not afford legal assistance..$^{55}$

Hector's assessment that condemned prisoners did not perceive their execution as inevitable and were committed to contesting their sentences also stands up to closer scrutiny. Interviewed in the late-1980s shortly after his death sentence had been reversed on appeal, one prisoner who had entered death row in 1976 commented that, "despite the terrible conditions, most of the men live with hope that their cases will be reviewed and they will not hang". ${ }^{56}$ Ashwood likewise spoke of choosing "the way of survival", though he attributed his hope and faith to the will of God ${ }^{57}$ It is nonetheless clear that for many prisoners hope was not based only on faith, or on legal challenges or appeals for clemency that were dependent on outside support and decision-making, but was intimately bound up with their daily struggles for survival on death row. Indeed, the battles that played out over Jamaican capital punishment in courtrooms in both Kingston and London during the 1970s, 1980s and 1990s could not have taken place without the more prosaic conflicts that were fought on death row through coordinated acts of convict resistance.

Hector himself gave three specific examples of this connection between events on death row and the struggle against individual convictions and the death penalty more broadly. The first concerned prisoners' correspondence with their attorneys and other supporters on the outside. Hector wrote that the "free flow of letters" was "crucial to the intelligent and calculated struggle for life on the Row", but access to stationary was heavily restricted and prison guards often blocked communications. ${ }^{58}$ An informal grapevine involving prisoners who were not on death row consequently became the main link between condemned inmates and the outside world. The system was based on an illegal trade in prison supplies that were stolen by prisoners and then exchanged with corrupt guards in return for contraband, including "stamps and stationary and outgoing letters". ${ }^{59}$ The guards would sell the prison supplies on the outside, while the prisoners would 
trade the contraband amongst themselves, including to death row prisoners, in particular those, like Hector, who were widely believed to be innocent. In this way, Hector was able to send letters to church groups and human rights organisations, including the UN Commission on Human Rights and Amnesty International, which took up his case as part of a broader campaign against the execution of convicts who had been under the age of 18 when they committed their alleged offences. The case attracted widespread publicity. At a press conference in England, the black civil rights activist Angela Davis - herself a former prisoner - drew attention to Hector's plight in an illustration of the pan-African dimension of the anti-death penalty movement. Meanwhile, back in Kingston, hundreds of ordinary citizens signed petitions in support of clemency. ${ }^{60}$

A second example of coordinated prisoner activism in Hector's autobiography focused on the aftermath of the Warder Clarke kidnapping. Hector described the kidnapping as a "spark" that set off resistance across the Jamaican prison system. Another warder was taken hostage at the recently established Gun Prison and the convicts involved won an audience with the national security minister. Shortly afterwards, a riot broke out at Tamarind Prison Farm, and, at the General Penitentiary in Kingston - Jamaica's largest prison, three more warders were seized by inmates and members of a parliamentary subcommittee on crime were sent to negotiate their release. ${ }^{61}$

Back at the St Catherine District Prison, inmates on death row prepared meticulously to give testimony about the conditions of their incarceration to the Barnett Commission. Along with men from the general prison population, who they communicated with through ventilators in the prison walls, they formed the Prisoners' United Liberation League (PULL), an organisation that advocated far-reaching reforms across the Jamaican penal system and within a year claimed to have nearly 400 members, before it was outlawed. While the inquiry was still in progress in March 1975, news arrived that the executions of four men were to be carried out imminently. Three of the men broke away from their guards and armed themselves as they were transferred from death row to the cells adjacent to the gallows. The army was called in to restore order, the men were recaptured and viciously beaten and the prison put on lock-down. Through the prison grapevine and PULL, however, other death row inmates were able to send off thirty-six "notes and messages" alerting relatives, attorneys and human rights groups to the impending executions. They also drew up a petition for a stay of execution, which was signed by hundreds of inmates and sent to the Governor-General. ${ }^{62}$ Ronnie Thwaites, an attorney for one of the men who was scheduled to be hanged, told the Barnett Commission of Inquiry in 1975 that "the atmosphere at the prison was once again 'electric' because of the decision to hang the men", and the Commissioners voiced their dismay that the executions had been scheduled while their investigations were ongoing. ${ }^{63}$ The executions were eventually stayed for one week to allow for the Commission to submit an interim report for the consideration of the Governor-General and Privy Council, and then further postponed until the Commission had completed its work. ${ }^{64}$ Two of the four men - Carl Bryan and Noel Absolom - were finally hanged in late-February 1976, but Everton McFarlane and Errol Gayle had their sentences commuted to life imprisonment. On the eve of Bryan and Absolom's executions, prisoners protested once again, sending a news release to the Legal Aid Clinic for distribution to the media claiming that both men were innocent and calling for an investigation into the case. ${ }^{65}$ 


\section{Clemency and the Politics of the Death Penalty in 1970s Jamaica}

26 By the time that Carl Bryan and Noel Absolom were executed, the death sentences imposed on Mario Hector and several of the other condemned men involved in acts of resistance at St Catherine District Prison had been commuted to life imprisonment and the prisoners transferred to the Kingston General Penitentiary. Hector had learned that his life was to be spared from a radio news broadcast shortly after lunch on 12 September 1975. The Jamaica Privy Council, which reviewed all death sentences and issued recommendations on clemency to the Governor-General, was not required to explain its decisions, but in this case did so with reference to Hector's age. Along with Eaton Baker, Paul Tyrell, Horace Coates and Everton McFarlane, whose sentences were commuted on the same day, the crime for which Hector was condemned to death had been committed when he was under the age of 18 and he had been sentenced in line with the provisions of a controversial 1948 amendment to Jamaica's Juvenile Law that prohibited capital punishment only for offenders who were under 18 at the time of sentencing. ${ }^{66}$ Appeals against the Juvenile Law and the controversy and delays they generated were crucial to the fate of individual prisoners and - more broadly - helped create the conditions that sustained a broader attack on the death penalty throughout the rest of the decade, notably by drawing national and international attention to the law's capriciousness and fallibility, and contributing to the long delays in enforcing death sentences that allowed for the emergence on death row of a group of radical prisoners united in common cause.

Since the late-1960s, Jamaica's juvenile sentencing laws had been applied inconsistently by local courts and subjected to constitutional challenges before the Judicial Committee of the Privy Council in London. The law was first reviewed in the case of Maloney Gordon, who was condemned to death in November 1967 for the murder of Andrew Barton in Kingston. Court records indicate that Gordon's sentencing was based on entirely inconclusive evidence of his age and a misunderstanding of the law on the part of the judge. After the jury had returned its verdict, the trial judge sought clarification of Gordon's age at the time of the murder rather than - as the law required - at the time of the trial. The prosecution hastily obtained a birth certificate from Spanish Town for a child named Eustace Gordon who had been born to one Violet Bailey on 28 September 1948. Bailey was called to testify and identified herself as the mother of the accused. She explained that Eustace was her eldest son and, as he had been just 18 years and 4 months old when Barton was killed, Maloney - his younger brother - could not have been older than 17 at that time. This evidence did not persuade the judge, however, who explained that he had observed the accused in the course of the trial and found "as a fact from all the circumstances that on the date [of the murder] he was over eighteen years old". ${ }^{67}$

After an initial appeal on the facts of the case was dismissed in 1968, the case was brought before the Judicial Committee of the Privy Council, which quashed Gordon's death sentence due to the inconclusive manner in which the trial judge had ascertained his age and, further, ruled that Jamaican courts had "no jurisdiction to pass sentence of death" upon persons who were under 18 at the time of their offence. This judgment was based on schedule 2. 20 (7) of Jamaica's 1962 constitution, under which no person was to suffer a more severe penalty for any criminal offence than "the maximum penalty which might have been imposed for that offence at the time when it was committed". The decision also 
rested on the principle that the Jamaican Constitution trumped the common law, but this formulation was at odds with an earlier Judicial Committee ruling in the case of Director of Public Prosecutions v. Nasralla (1967), which found that the Constitution did not establish any new rights that were inconsistent with the common law as it had stood when the Constitution was adopted in $1962 .{ }^{68}$ As such, Gordon's case did not bring a final resolution to the legal and constitutional questions concerning Jamaica's death penalty laws and young offenders. ${ }^{69}$ On the contrary, the Jamaican Court of Appeal repeatedly ignored the judgment over the following years and instead relied on Nasralla to support rulings that offenders should only be treated as juveniles if they were under the age of eighteen when sentenced rather than at the time of their offence. This position was established in the non-capital cases of R. v. Williams (1970) and R. v. Martin Wright (1972) and these were subsequently cited as precedents later in 1972 when the Court dismissed the appeals of Eaton Baker and Paul Tyrell against death sentences imposed for their part in the Hill Top Prison murder, which was committed in 1969 when they were only seventeen. ${ }^{70}$ In due course, the matter was taken once more before the constitutional court, but the Judicial Committee upheld the death sentences, reversing its earlier judgment in Gordon and dismissing Baker and Tyrell's appeal in a split 3-2 decision announced in May 1975. ${ }^{71}$

In the majority judgment in Baker, delivered by Lord Diplock, the justices declared themselves unwilling to deviate from the literal meaning of Jamaica's juvenile capital punishment law even while recognising that it could result in "a degree of inequality of punishment between two persons of the same age who committed similar crimes on the same day", but were tried and sentenced at different times. ${ }^{72}$ The justices nonetheless gave a strong steer in support of clemency for the appellants, drawing attention to the potential for the prerogative of mercy to serve as a mechanism for mitigating unequal punishments in appropriate cases. In a dissenting judgment that was damning in its assessment of his colleagues' reasoning, Lord Salmon advocated for clemency more explicitly. Condemning the Juvenile Law as "barbarous and absurd," Salmon rejected the view that Jamaican legislators could have deliberately introduced "a law having such strange and palpably inhuman results in the hope that they might be rectified by the prerogative of mercy". ${ }^{73} \mathrm{He}$ also expressed the hope that, when assessing the case for clemency, the Jamaican Privy Council might take into account the fact that the appellants had spent four years under sentence of death. ${ }^{74}$

The extent to which the Privy Council's decision to grant clemency was influenced by the length of time that Baker and Tyrell had spent on death row is unknown. No execution had previously been carried out in Jamaica so long after a sentence of death had been imposed, but it would not have been wholly exceptional if they had been hanged. In the early-1970s, three men went to the gallows after almost three years each on death row (Aston White, Alexander Francies, Lawrence Sinclair) and in the early-1980s several prisoners were executed after delays of more than seven years. A commuted sentence on the grounds of age, likewise, was not an inevitable outcome of the clemency process. Official death certificates indicate that at least two men may have been under 18 at the time of murders for which they were executed in the late-1960s and early-1970s, while Everton MacFarlane was only 17 in early-1975 when the Jamaica Privy Council upheld his death sentence and issued a warrant for his execution to proceed. ${ }^{75}$

31 In this light, the efforts by death row prisoners and others to challenge and destabilise the death penalty in the early 1970s appear all the more significant to saving the lives of MacFarlane and the other young prisoners whose sentences were commuted in 
September 1975. Without the kidnapping of Warder Clarke, the resultant Barnett inquiry, and the concerted protests by prison inmates and human rights groups against executions in March 1975, MacFarlane would have died long before the Privy Council decided to grant clemency. Furthermore, a chorus of opposition to the execution of juvenile offenders, which included repeated petitions from Amnesty International, prompted an amendment to the Juvenile law in 1976 such that punishment would thereafter be determined by an offender's age at the time an offence was committed rather than at sentencing. ${ }^{76}$ Irrespective of its constitutional merits, imposing the death penalty on juvenile offenders had become politically unacceptable in Jamaica.

While the actions of Hector and other condemned prisoners had done much to encourage debate on the future of capital punishment, it is important to recognise that theirs were not lone voices and their acts of resistance on death row took place against an unprecedentedly favourable backdrop outside the prison walls - both nationally and internationally. There was at this time unprecedented questioning of the probity and justice of capital punishment in many sections of Jamaican society, notably by the Jamaica Council for Human Rights (JCHR) and church groups, as well as Amnesty International, which wrote annually to the Governor-General from 1974 to 1976 on the issue of juvenile executions. ${ }^{77}$ Several lawyers associated with the JCHR, including Dennis Daly, persistently challenged death sentences through the courts and helped to mobilise public discontent with the judicial system that resonated with complaints that death row prisoners made about their treatment in the courts when interviewed by the Barnett Commission. The suspension of executions in the United States for a five year period following the Supreme Court's ruling in Georgia v. Furman (1972) as well as growing opposition to capital punishment across Western Europe, also contributed to an international context in which the death penalty was under siege as never before. On several occasions during the 1970s, American and European activists protested death sentences in the Caribbean, including notably in the case of Michael X, hanged in Trinidad in 1975 and the case of Larry Tacklyn and Erskine Burrows, whose execution in Bermuda in December 1977 was widely condemned and prompted several days of riots on the island. It is reasonable to suggest that the death penalty had not been so political salient in the Anglophone Caribbean since the brutal repression of the Morant Bay uprising in 1865.

In 1977, the Minister of Justice, Carl Rattray, himself a committed advocate of penal reform and abolition of the death penalty, identified the case of Michael Bernard as a key reason why around 2,000 people had signed a JCHR petition calling for an investigation into the use of the death penalty. Bernard had been found guilty of shooting dead 18year-old Clifton Stevenson in Tivoli Gardens in June 1972, mainly on the basis of testimony from a 14 year old girl, Paulette Stewart, who appeared at the original trial as the sole eye-witness to the crime. The conviction was later upheld on appeal, but nearly eighteen months after Bernard's original trial, in late-1974, Stewart retracted her evidence and claimed that a man named Shorty Lloydie had threatened to shoot her if she did not identify Bernard as Stevenson's killer. ${ }^{78}$ Following this revelation, a new petition seeking clemency for Bernard was submitted to the Governor General who sought guidance on the case from the Court of Appeal. At hearings in July 1975, three appellate judges concluded unanimously that there was no merit to Stewart's new version of events and it was in fact her new testimony rather than the original evidence that was given under duress. Notwithstanding this finding, Bernard's death sentence was eventually 
commuted on the same date as Mario Hector's due to his status as a juvenile, but the case left deep scars. In a submission to Cabinet in 1977, Rattray warned that there remained acute public distrust in the judiciary and the unregulated work of the Jamaica Privy Council on clemency appeals in death penalty cases. He continued, "the massive public support for Michael Bernard was clearly rooted in the revulsion of the general public in having the execution in their name of a man in respect of whom there might exist even the scintilla of a doubt". ${ }^{79}$

The death penalty by this time was in a state of paralysis in Jamaica, a further indication of the long term impact of the events set in train by the protests on death row in 1974. The Jamaica Privy Council nominally continued with its regular function of reviewing capital sentences and determining whether or not the law should take its course, but while it commuted at least twenty-one death sentences between April 1976 and May 1979, it issued no execution warrants during that time, seemingly on account of ongoing political machinations about the future of capital punishment. ${ }^{80}$ In the wake of the 1977 petition and with the number of prisoners on death row growing to unprecedented and barely sustainable levels, a select committee was formed in the Jamaica House of Representatives to consider the revisions to the country's capital laws proposed by the Barnett Commission. After undertaking only cursory enquiries, the committee recommended that no changes should be made. Dissatisfied with this outcome, the Cabinet returned the issue to committee in early-1978 but with the same result, except that the committee noted specifically on this occasion that it lacked the resources to conduct a full investigation into the "effect of capital punishment as a deterrent to crime". ${ }^{81}$ In the wake of this report, Rattray called for a formal suspension of the death penalty pending a more detailed study of its effects.$^{82}$ This proposal was rejected in the House of Representatives on 30 January 1979 by a narrow vote of twenty-three to twenty, but a week later the Senate voted in favour of an eighteen-month suspension of executions. ${ }^{83}$ Commentary in Jamaica's leading daily newspaper, the Gleaner, expressed exasperation at the state of affairs, which it believed left the Governor-General and Jamaica Privy Council "in a most unenviable position", imposed psychological cruelty on condemned prisoners by delaying executions and raising hopes of a reprieve, and insulted public opinion, which, it argued, supported the continuation of hanging. "The present situation", the Gleaner concluded, "is chaotic." ${ }^{84}$

By the end of the year only a modicum of order had been restored and the future of the death penalty in Jamaica remained shrouded in uncertainty. In June 1979, Rattray established the Fraser Commission to investigate the future of the death penalty ${ }^{85}$ The Jamaica Privy Council, meanwhile, began a review of the cases of all condemned prisoners and in May 1979 commuted the death sentences imposed on Winston Williams and three other men to life imprisonment. The reasons for the decision in Williams's case are opaque, but might have reflected that the life of his accomplice, Hector, had already been spared, or the fact that he had spent more than seven years on death row. Critically - and in contradistinction to prisoners who were executed after similarly lengthy spells under sentence of death just a few years later - Williams had long since exhausted his legal appeals, so the delay in enforcing his death sentence was largely due to government inaction, which once again attests to the significant impact of the Warder Clarke kidnapping on the fate of the death row prisoners who participated in it. issued warrants for the execution of eight other prisoners. A court injunction issued on 
the eve of the first of these scheduled hangings caused a further delay and it was not until August 1980 - when the Senate's eighteen-month moratorium had expired but the Fraser Committee had yet to report - that Conrad Dwyer eventually became the first person hanged in Jamaica in more than four years. A further fifty-eight men would die on the gallows at St Catherine District Prison over the next eight years, including Stanford Dinnal and Nathan Foster who were put to death on 18 February 1988 in the last Jamaican executions to date.

\section{Conclusion}

In January 1979, four months before Winston Williams left death row, he was joined in the cells by Earl Pratt and Ivan Morgan, men who would spend far longer under sentence of death even than he did. Fourteen years and three scheduled execution dates passed before their sentences were commuted by the Judicial Committee of the Privy Council in a judgment that ruled the execution of a condemned prisoner more than five years after sentencing to be unconstitutional. ${ }^{86}$ Since that time, the Judicial Committee's judgment in Pratt, legal reforms including an end to mandatory sentencing in murder cases and a series of further death penalty rulings by the Judicial Committee in cases from across the Commonwealth Caribbean have served to perpetuate the suspension of executions in Jamaica. Amidst high public support for the death penalty, some steps have been taken to remove the legal barriers to the enforcement of capital sentences. Most notably, as a result of the Charter of Fundamental Rights and Freedoms (Constitutional Amendment) 2011, the requirement imposed by Pratt that executions should be carried out within five years of sentencing no longer applies. This has not, however, led to the resumption of hangings. Murder is now mostly tried as a non-capital crime and in 2016 there was only one prisoner under sentence of death. ${ }^{87}$

Mario Hector's account of his time on death row demonstrates that the culture and law of capital punishment and the origins of anti-death penalty activism in Jamaica are rooted not only in appellate proceedings and the associated campaigning work of national and international lawyers and human rights organisations, but also in events instigated by the many condemned men within the walls of St Catherine District Prison dating back to the early-1970s. The diverse forms of individual and collective action in which death row prisoners engaged had far reaching consequences. While these consequences did not include the abolition of capital punishment, death row resistance helped to revolutionise the political debate about the death penalty in Jamaica and the lives of many death row prisoners were spared as a result. Furthermore, prisoners' resistance was one of the key reasons for the long delays in the execution of death sentences on which anti-death penalty jurisprudence would turn for the next two decades.

The history of Jamaica's death row in the 1970s opens up new research questions about what was a critical moment for capital punishment globally, as the ranks of abolitionist countries swelled, Amnesty International launched a campaign for universal abolition, and international bodies including the Council of Europe and United Nations took steps towards restricting the death penalty in international law. On the basis of Jamaica's experience, further investigation is required of the contributions - direct and indirect, intended and unplanned - that condemned prisoners in all countries made to the advance of the abolitionist cause in this era. This must involve, in particular, study of prisoners' everyday struggles to endure life under sentence of death and the intersection of those 
struggles with legal appeals against individual death sentences and wider political and human rights campaigns against the death penalty. The Jamaican case shows, too, that more needs to be done to integrate countries in the Global South into histories of capital punishment - especially its abolition - that to date have overwhelmingly centred on North America and Western Europe.

\section{BIBLIOGRAPHY}

References

Amnesty International, Jamaica, the death penalty: report of an Amnesty International Mission to Jamaica, London, Amnesty International Publications, 1984.

Ancker, C., Determinants of the Death Penalty: a Comparative Study of the World, London, Routledge, 2004.

Banner, S., The Death Penalty: an American History, Cambridge, Mass., Harvard University Press, 2003.

Barnett, L. G., Report of commission of enquiry into incidents which occurred at St. Catherine District Prison [on the] 27th December, 1974, Kingston, the Commission, 1975.

Barrett, I. R., “The Ombudsman in Jamaica”, Social and Economic Studies, 1985, 34, 1, pp. 59-75.

Berger, D., Captive Nation: Black Prison Organizing in the Civil Rights Era, Chapel Hill, University of North Carolina Press, 2014.

Blue, E., "The culture of the condemned: pastoral execution and life on death row in the 1930s", Law, Culture and the Humanities, 2011, 9, 1, pp. 114-132.

Clarke, C., "Politics, violence and drugs in Kingston, Jamaica", Bulletin of Latin American Research, 2006, 25, 3, pp. 420-440.

Cunningham, M. D. \& Vigen, M. P., "Death Row inmate characteristics, adjustment, and confinement: a critical review of the literature", Behavioral Sciences and the Law, 2002, 20, pp. 191-210.

Fitzgerald, E., "Commonwealth Caribbean”, in Hodgkinson, P. Rutherford, A. (eds), Capital Punishment: Global Issues and Prospects, Winchester, Waterside Press, 1996, pp. 143-154.

Garland, D., Peculiar Institution: America's Death Penalty in an Age of Abolition, Cambridge, Mass., Harvard University Press, 2010.

Harrington, J., "The challenge to the mandatory death penalty in the Commonwealth Caribbean", The American Journal of International Law, 2004, 98, 1, pp. 126-140.

Harriott, A., Understanding crime in Jamaica: new challenges for public policy, Kingston, University of the West Indies Press, 2003.

Hector, M., Death Row, London, Zed Books, 1984.

Hellerstein, W.E. \& Whitman, L., Prison Conditions in Jamaica, May 1990: An America's Watch Report, New York, Human Rights Watch, 1990. 
Hickling, R.H., “The Jamaican Gun Court Act”, Malaya Law Review, 1974, 16, pp. 248-259.

Highet, K., Kahale III, G. \& Phillips, B., "Pratt \& Morgan v. Attorney-General for Jamaica”, The American Journal of International Law, 1994, 88, 4, pp. 775-783.

Hood, R. \& Hoyle, C., The Death Penalty: a Worldwide Perspective, Oxford, Oxford University Press, 2008.

Inter-American Commission on Human Rights, Report on the Situation of Human Rights in Jamaica, Washington, D.C., Inter-American Commission on Human Rights, 2012.

Jamaica, Department of Statistics, Annual Abstract of Statistics, Kingston, Department of Statistics, 1953-1989.

Johnson, D. T. \& Zimring, F. E., The Next Frontier: National Development, Political Change, and the Death Penalty in Asia, Oxford, Oxford University Press, 2009.

Johnson, R., Condemned to Die: Life Under Sentence of Death, New York, Elsevier, 1981.

Knowles, J. B. "Capital Punishment in the Commonwealth Caribbean: colonial inheritance, colonial remedy?" in Hodgkinson, P., Schabas, W. A. (eds) Capital Punishment: Strategies for Abolition, Cambridge, Cambridge University Press, 2004, pp. 282-308.

Morrison, D. "The Judicial Committee of the Privy Council and the death penalty in the Commonwealth Caribbean: studies in judicial activism", Nova Law Review, 2006, 30, 3 , pp. 403-424.

Report of the Committee to Consider Death as a Penalty for Murder in Jamaica, 1981.

Rubin, A. T., "Resistance or friction: understanding the significance of prisoners' secondary adjustments", Theoretical Criminology, 2015, 19, 1, pp. 23-42.

Schabas, W. A., The Abolition of the Death Penalty in International Law, Third Edition, Cambridge, Cambridge University Press, 2002.

Smith, A., "Not 'waving' but drowning: the anatomy of death row syndrome and volunteering for execution", Public Interest Law Journal 2008, 17, pp. 237-254.

Thompson, H. A., Blood in the Water: the Attica Prison Uprising of 1971 and its Legacy, New York, Pantheon, 2016.

Vaz-Green, D., A Passage Through the Valley of Death: the Anthony 'Fines' Ashwood Story, Hartford, CT, Green Oasis, 2005.

Westervelt, S.D. \& Cook, K.J., Life after Death Row: Exonerees' Search for Community and Identity , Piscataway, NJ, Rutgers University Press, 2012.

\section{NOTES}

1. "Man arrested on second murder charge", Gleaner, 23 Nov. 1970, p.10; "Bank Murder Trial", Gleaner, 25 Feb. 1972, p.4.

2. Hector (1984, pp.6-7).

3. See, for example, Schabas (2002, pp.341-344); Fitzgerald (1996, pp.143-153); Harrington (2004, pp.127-132); Knowles (2004, pp.282-308); Morrison (2006, pp.403-424).

4. Barnett (1975); Report of the Committee to Consider Death (1981, p.1).

5. For an overview of literature on death row inmates and conditions, see Cunningham \& Vigen (2002, pp.191-210). 
6. Johnson (1981, p.44). The phrase "living death," was used by condemned men in Alabama when interviewed by Johnson in 1978.

7. Johnson (1981, p.148), cited in Smith (2008, p.245).

8. See, for example, Ancker (2004); Banner (2003); Garland (2010); Hood \& Hoyle (2008); Johnson

\& Zimring (2009); Schabas (2002).

9. Blue (2011, p.115).

10. Blue (2011, p.116).

11. “Cooper's Hill killer hangs self," Gleaner, 21 April 1972, p.1.

12. Rubin (2015, pp.24 \& 36-37) [italics in original]

13. There is an extensive literature on the prisoners' rights movement in the United States, but see in particular Berger (2014, p.2) and Thompson (2016).

14. Hector (1984, p.29).

15. On death row conditions since the 1970s, see Hellerstein (1990, pp.17-22); Amnesty International, Jamaica: Proposal for an Inquiry into Deaths and Ill-treatment of Prisoners in St Catherine District Prison, Amnesty International Index, AMR 38/04/93 (1993, pp.2-3); InterAmerican Commission on Human Rights (2012, pp.66-68).

16. As the number of condemned prisoners increased during the 1970s, other cells had to be used where prisoners slept on bug-ridden mattresses on the floor. Vaz-Green $(2005$, p.90).

17. Barnett (1975, pp.4-5).

18. Hector $(1984$, p.16).

19. Hector (1984, p.15). On boredom among US death row inmates, see Johnson (1981, pp.47-48); Westerweld, Cook (2012, p.112).

20. Murder was the only offence for which the death penalty was imposed in this period.

21. Figures on reported murders for 1962-78 in Report of the Committee to Consider Death (1981, p.42). Figures for 1979-82 in Daily Gleaner, 16 March 1983.

22. Clarke (2006, p.428); Harriott (2003, pp.91-92).

23. Report of the Committee to Consider Death (1981, p.21).

24. Jamaica, Department of Statistics (1953-1989).

25. Persons Sentenced for Murder, including infanticide (fiscal Year). Source: Criminal Investigation Department, Jamaica Annual Abstract of Statistics, 1953 to 1989.

26. I have found evidence of three women sentenced to death in 1970s Jamaica. Pearleta Segree, Viola Watson and Icema Braham. Their sentences were commuted to life imprisonment in 1972 and 1975 respectively. See "4 on Death Row get reprieve," Gleaner, 28 July 1972, p.18; "Mother of eight sentenced to death," Gleaner, 21 October 1972, p.2; "Bernard will not Hang," Gleaner, 13 September 1975, p.1. The last woman executed in Jamaica was Agnes Hire, who was hanged in 1891. See Gleaner, 16 September 1891, p.3.

27. The right of appeal in murder cases was introduced in Jamaica in the 1930s, but the appeal process became lengthier after independence, as the new Jamaican Constitution and shifts in British and international death penalty law and practice opened up new avenues for review. These developments also made the Judicial Committee of the Privy Council more receptive than in earlier periods to complaints against the death penalty, though it would be several more years before JCPC rulings significantly restricted capital punishment. Appellate proceedings were also facilitated by local shifts in administrative practice and human rights culture, including the extension of legal aid, the formation of the Jamaican Council for Human Rights in 1968 (and the associated work of abolitionist lawyers) and the creation of the office of the ombudsman in 1978 with powers to investigate complaints of "injustice or breaches of human rights" by the state. On the ombudsman, see Barrett (1985, p.69).

28. All figures calculated by author based on dates of sentencing and execution. The seven men held for more than seven years before execution were Anthony Forbes, Noel Riley, Elijah Beckford, Fernando Marks, Andrew Scarlett, Francis Woodhouse, and Nathan Foster. Earl Pratt 
and Morgan were condemned to death on 15 January 1979 and spent more than fourteen years on death row before their sentences were commuted in line with the Privy Council's ruling in Pratt and Morgan v. Attorney-General for Jamaica [1993].

29. Amnesty International (1984, p.11).

30. Report of the Committee to Consider Death (1981, pp.18-20).

31. Report of the Committee to Consider Death (1981, pp.20-23).

32. Hector (1984, p.13).

33. Vaz-Green (2005, p.100).

34. Psychological Report, Ivan Morgan, 11 April 1991, Pratt and Morgan v. The Attorney General for Jamaica and another (Jamaica) [1993], UK Privy Council, 37. Morgan's condition is consistent with what has been identified as death row syndrome, the "psychological effects for inmates that can result from extended periods of time spent on death row, in harsh conditions, coupled with the unique stress of living under sentence of death." Smith (2008, p.242).

35. In 1974, the Barnett commission had recommended an end to the practice of carrying executed bodies on noisy carts, but Ashwood's recollections indicate this had not been acted on. See Cabinet Submission, Report of Commission of Enquiry into incidents which occurred at the St. Catherine District Prison on 27 December 1974, Jamaica Archives, 1B/31/371 1975; Vaz-Green (2005, p.104).

36. "Condemned to die - the story of a former death row inmate," Gleaner, 7 September 2007.

37. Hector (1984, p.57).

38. Barnett (1975, pp.26-28).

39. Barnett (1975, pp.28-29).

40. Cabinet Submission, Report of Commission of Enquiry into incidents which occurred at the St. Catherine District Prison on 27 December 1974, MNSJ-18, Jamaica Archives, Spanish Town, Jamaica.

41. Barnett (1975, p.24).

42. Hector (1984, p.32).

43. Hector (1984, pp.33-34).

44. Hector (1984, p.39).

45. The "non-implementation of some of the recommendations contained in the Report of the Barnett Commission of Enquiry" was identified as a primary cause of rioting at the St Catherine District Prison in August 1976. See Cabinet Submission, "Report on the causes and circumstances surrounding the incidents which occurred at the St. Catherine District Prison on the 26th August 1976" (Farquharson's Report), 2, Jamaica Archives, 1B/31/179 1977.

46. Hector (1984, p.36).

47. Hector (1984, p.57).

48. Hector (1984, p.30).

49. Hector (1984, p.19).

50. Hector (1984, p.30).

51. Barnett (1975, p.25); Hector (1984, acknowledgments, np).

52. As early as 1950, the annual report of the Visiting Committee of the St Catherine District Prison noted critically that "political feeling is present within the Institution to a greater extent than is desirable, or natural, rival factions whilst not conflicting openly, withholding cooperation as fully as should be expected in an Institution of the sort". Annual Report of the Visiting Committee of the SCDP for 1950, St. Catherine District Prison: correspondence with Wardens and others; minutes of meetings, reports etc. Nos 73-76. (1946-50), Jamaica Archives, Spanish Town, 4/19/3a/74.

53. "Man hanged", Gleaner, 20 October 1971, p.2. The term "comrade" here indicates identification with the PNP.

54. Report of the Committee to Consider Death (1981, p.22). 
55. Vaz-Green (2005, chapter 14).

56. Hellerstein, Whitman (1990, p.21).

57. Vaz-Green (2005, chapter 14).

58. Hector (1984, p.59).

59. Hector (1984, p.61).

60. Hector, (1984, p.64).

61. Hector (1984, pp.84-85).

62. Hector (1984, pp.88-93).

63. "Interim report in prison inquiry on Tuesday", Gleaner, 30 March 1975, p.2.

64. "Interim report in prison inquiry on Tuesday", Gleaner, 30 March 1975, p.2.

65. "Prisoners protest ... Convicts to be hanged today", Gleaner, 25 February 1976, p.2.

66. Hector (1984, pp.99-100); "Bernard will not Hang”, Gleaner, 13 September 1975, p.1.

67. Maloney Gordon v. The Queen, 11 Jamaica Law Reports (J.L.R.) (1969).

68. Patrick Nasralla, a Kingston furniture dealer, was tried in February 1963 for the murder of one of his employees, Gilbert Gillespie. He was acquitted of the capital charge, but the jury failed to agree on whether he was guilty of the lesser crime of manslaughter. Two years later, defence lawyers successfully appealed against prosecution efforts to try Nasralla for a second time for Gillespie's manslaughter, resting their case on section 2. 20 (8) of the Jamaican Constitution, which guards against double jeopardy. "Nasralla Case", Gleaner, 19 October 1966, p.2; "Judgment in Case against Nasralla", Gleaner, 17 March 1967, p.5; Director of Public Prosecutions v. Nasralla [1967], UKPC 3.

69. Maloney was ordered to be detained at Her Majesty's pleasure. Maloney Gordon v. R. [1969], UKPC 29.

70. Williams was convicted of aggravated robbery in the Home Circuit Court in Kingston on 3 October 1969 and sentenced to five years imprisonment and four lashes. Born in February 1952, Williams appealed his sentence on the grounds that juveniles could not be sentenced to imprisonment or lashes and he had been only 16 years and 7 months when the crime was committed in September 1968. Although the court rejected this interpretation of the juvenile law, it upheld Williams's appeal on other grounds, namely that following R. v. Brown, 7 WIR (47), the punishment was excessive and under the provisions of the Larceny Law and the Probation of offenders Law punishments should not be imposed that could have a detrimental effect on the offender. The court accepted that a long term of imprisonment with hardened criminals would be detrimental to a young offender like Williams. See "Court here dissents from Privy Council ruling against death penalty", Gleaner, 22 August 1970, p. 4. In R. v. Martin Wright, the Court confirmed that it was not bound by Gordon on the grounds that, first, the judgment was per incuriam, as it had not engaged with the earlier findings in Nasralla, and, second, the Juveniles Law predated the Jamaica Constitution and therefore could not be rendered inconsistent with it. R. v. Martin Wright (1972), 12 J.L.R; Baker v. R. (1975), 13 J.L.R.

71. Baker v. R. (1975), 13 J.L.R.

72. Baker v. R. [1975], UKPC 22, Majority Judgment, 5.

73. Baker v. R., [1975], UKPC 22, Minority Judgment, 11.

74. Baker v. R., Minority Judgment, 16.

75. Calculating the exact age of executed prisoners is difficult due to the unavailability and unreliability of birth records. The two men who appear from their death certificates to have been executed for murders committed when under 18 were George Grant, executed as an 18 year old in 1969 for a murder committed 18 months earlier, and Lawrence Sinclair, whose age was recorded as 20 when he went to the gallows in 1972 for the 1969 murder of Stafford Williamson. Sinclair's age was contested and he was sentenced on the basis of a birth certificate presented to the court that showed him to have been born in 1950. Two other prisoners - Clifton Larman and Carlton Bowen - were sentenced to death in August 1963 when death records show they can have 
been no older than 18. For all death records, see "Jamaica, Civil Registration, 1880-1999", Database with images, FamilySearch, http://FamilySearch.org, accessed 2015, Registrar General's Department, Spanish Town.

76. The Death Penalty: A Survey by Country. Jamaica, Amnesty International Country Dossiers Catalogue, ACT 05/03/79.

77. "Don't abolish the death penalty", Gleaner, 26 September 1977, p.8.

78. Text of Report to G-G on Michael Bernard', Gleaner, 5 September 1975, p.22.

79. Carl Rattray, Cabinet Submission: Capital Punishment, 1B/31/98 - 1977, Jamaica Archives, Spanish Town, Jamaica; "Rattray gets petition on death penalty", Gleaner, 31 January 1977, p.1.

80. Amnesty International (1984, p.5).

81. Amnesty International (1984, p.7).

82. Amnesty International (1984, p.7).

83. Amnesty International (1984, p.8); "House votes to retain capital punishment", Gleaner, 31 January 1979, p.1; "Senate votes for suspension of death penalty", Gleaner, 10 February 1979, p.1.

84. “A Decision, Please!”, Gleaner, 16 April 1979, p.6.

85. Report of the Committee to Consider Death (1981, p.1).

86. See Judgment, Pratt and Morgan v. The Attorney General for Jamaica and another (Jamaica) [1993], United Kingdom Privy Council (UKPX) 37. See also Highet, Kahale III, Phillips (1994, pp.775-783).

87. See Charter of Fundamental Rights and Freedoms (Constitutional Amendment) Act 20111, United Nations Treaty Body Database, http://tbinternet.ohchr.org/Treaties/CCPR/.../ INT_CCPR_NGO_JAM_103_9245_E.pdf, accessed 2016; "Death Sentence for Hanging”, Gleaner, 9 May 2016.

\section{ABSTRACTS}

Scholarship on the modern death penalty has mostly focused on issues related to abolition. It has tended to prioritise legal and constitutional developments and the role of international human rights standards in shaping global capital punishment laws and practices. National studies have been overwhelmingly concerned with the United States. This article opens up several new perspectives on recent death penalty history through an examination of events in Jamaica in the 1970s. In particular, it identifies death row as an important site of resistance to executions. In reconstructing the conditions of Jamaica's death row and the dramatic struggles over the fate of individual prisoners that played out in the cells as well as in the courts, it makes the case that a full understanding of opposition to the death penalty must incorporate the experiences, actions and ideas of condemned prisoners alongside the work of activists, lawyers, judges and politicians. The article also uncovers the local roots of opposition to the death penalty in Jamaica. This challenges accounts that depict the de facto moratorium on executions that has been in place across much of the Anglophone Caribbean since the early-1990s as a form of neo-colonialism imposed by British and other international courts and at odds with local public opinion, law and penal culture. More generally, the article serves as a reminder of the continued importance of local context to the administration, enforcement and abolition of capital punishment, even in an era of growing international concern with executions.

Les recherches sur la peine de mort contemporaine ont principalement examiné les questions relatives à l'abolition. Elles ont eu tendance à mettre au premier plan les évolutions légales et 
constitutionnelles et le rôle des standards internationaux en matière de droits de l'homme dans la production des lois et des pratiques relatives à la peine capitale. Les études nationales se sont principalement concentrées sur les Etats-Unis. Le présent article - qui se penche sur les événements survenus en Jamaïque dans les années 1970 - ouvre plusieurs perspectives nouvelles sur l'histoire récente de cette peine. En particulier, il montre que les quartiers de condamnés à mort ont constitué des lieux importants de résistance aux exécutions. En reconstituant la situation dans ces quartiers et les luttes dramatiques qui se déroulaient tant en détention que dans les tribunaux autour du sort de certains prisonniers, il argue que pour comprendre complètement l'opposition à la peine de mort, il faut prendre en compte les expériences, les actions et les idées des condamnés comme des activistes, des avocats, des juges et des politiciens. Cet article dévoile également les racines locales de l'opposition à la peine capitale, contestant la thèse selon laquelle le moratoire de fait sur les exécutions - qui a régné dans une grande partie des Caraïbes anglophones depuis le début des années 1990 - constituait une forme de néocolonialisme imposé par les Britanniques et les tribunaux internationaux , et était en porte-àfaux avec l'opinion publique, le droit et la culture pénale locales. Plus généralement, cet article rappelle qu'il est toujours aussi important de tenir compte du contexte local de la mise en œuvre comme de l'abolition de la peine de mort, même à une époque qui voit s'accroître au plan international la préoccupation pour les exécutions.

\section{AUTHOR}

\section{JAMES CAMPBELL}

James Campbell is Associate Professor in American History at the University of Leicester where he works on the history of race, crime and punishment in the United States and the Caribbean. His publications include Slavery on Trial: Race, Class and Criminal Justice in Antebellum Richmond, Virginia (Florida, 2007), Crime and Punishment in African American History (Palgrave, 2012) and "Murder Appeals, Delayed Executions, and the Origins of Jamaican Death Penalty Jurisprudence", Law and History Review, 33,.2, 2015. He is currently working on a study of the death penalty in British Overseas Territories, University of Leicester - Jmc62@le.ac.uk 